Vol. I., part II., pp. 171-184. "Some details of flint fracture," "Proc. Prehist. Soc. of East Anglia," Vol. I., Part IV., pp. 442-445.

(11). Moir, J. Reid.-." On the further discoveries of flint implements beneath the base of the Red Crag of Suffolk." "Proc. Prehist. Soc. of East Anglia," Vol. II., Part I., pp. 12-31.

(12). Moir, J. Reid.- "The natural fracture of flint and its bearing upon rudimentary flint implements." "Proc. Prehist. Soc. of East Anglia," Vol. I., Part II., pp. 171-184. "Some details of flint fracture." "Proc. Prehist. Soc. of East Anglia," Vol. I., Part IV., pp. 442-445. "Flint fracture and flint implements." "Science Progress," No. 41, July, 1916, pp. 37-50.

\title{
THE ICKNIELD WAY IN EAST ANGLIA.
}

By W. G. Clarke.

Though it is now impossible to trace a connected road from end to end, there is little doubt that a series of trackways between Norfolk and Wiltshire have from very early times been known as the Icknield Way, and it is highly probable that originally they provided through communication between the south-west of England and the Norfolk coast. These trackways appear to be prehistoric, to have been utilised but never re-made by the Romans, avoiding the upper levels of the hills and skirting the slopes where the forest presumably ended. The adjacent country is dotted with hill-forts, barrows, and remains of the Neolithic and Bronze Ages.

There is much uncertainty as to the exact course of the Way, and there will probably never be general agreement, but local knowledge is a necessity, and for that reason I desire to record various facts which seem to me to strengthen the arguments for considering a road north-east of Royston to be the continuation of the tracks to the south-west, generically known as the Icknield Way.

\section{Royston to LACKFoRd BRIDGE.}

Almost in the centre of Royston the Icknield Way crosses the Ermine Street, and for many centuries, through the town and each side of it, marked the boundary between Hertfordshire and Cambridgeshire. Leaving Royston as the main road to Newmarket, two miles from the town the Icknield Way diverges to the right as a green lane, and for a little over a mile further continues as a county boundary, past Noon's Folly. It proceeds as a farm track through a sparsely-populated portion of Cambridgeshire, across the Bran Ditch by Ickleton Grange and Ickleton Abbey Farm, and across the Cam. It passes about a mile to the north of the important Roman station at Great Chesterford, and for a short distance again follows the boundary between Cambridgeshire and Essex. The Brent Ditch is crossed between Pampisford 
End and Abington Park, and after passing Pampisford Station and Bourn Bridge the Way turns north-eastward and follows the present turnpike between Royston and Newmarket. Between the two towns it crosses the famous Cambridgeshire Ditches. Until mediæval times the fens formed an almost impassable barrier to the north, the forest to the south, and the chalk ridge along which the Icknield Way ran was cut across by five big ditches, which an attacking force would have to capture successively by a frontal attack. In all cases the fosse lies to the westward, proof that the dykes were thrown up by a people whose territory lay to the east. There is the Bran Ditch by Heydon, two miles in length and apparently more recent than the Way, and the Brent Ditch by Pampisford, about a mile and three-quarters in length. Both adjectives probably have the meaning of "steep," though neither ditch could ever have been very imposing. The contrary was the case with the Wool or Worstead Street. The Fleam Dyke or Balsham Dyke almost equals the Devil's Dyke in size and surpasses it in length, being eleven miles compared to the seven miles of the latter, the former following the undulations of the ground and being therefore sinuous, while the Devil's Dyke is straight throughout. The Fleam Dyke is interrupted at Wilbraham Fen, which rendered a dyke unnecessary, and also shortly before its termination at Balsham. At the north end of the Fleam Dyke is Fen Ditton (or Dyke-ton); at the south end of the Devil's Dyke is Wood Ditton; and one of the Cambridgeshire Hundreds is Flendyshe or Fleam-ditch. In Morden and Wilbraham two "ores " were anciently reckoned as "toll," and it is supposed* that this may have been for the right of passage through the Fleam Dyke by the gap called Dungate, the coinage showing how strong the Norse influence must have been in the district. The Devil's Dyke is continuous throughout, and runs from Stetchworth across Newmarket Heath to Reach, upon the Cam, the rampart being 30 feet above the bottom of the ditch, and it has been computed + that it represents a bulk per foot $\mathbf{5 4 0}$ times as great, leaving out of account the fosse and the result of centuries of denudation. This dyke was mentioned by Abbo before the reign of Canute, and later by Matthew of Westminster, who records that King Edward the Elder fought a battle between " the two ditches of St. Edmund "- the Devil's Dyke and Fleam Dyke - in the year 902. In Saxon times the Devil's Dyke was the "mark" which divided East Anglia and Mercia, later the western boundary of the Liberty of St. Edmund, and until recently the boundary of the See of Norwich. The Manors of Brome Hall and Erwarton, Suffolk, were held by "leading all the men (200) of the counties of Suffolk and Norfolk to the King's wars in Wales from the Ditch of St. Edmund's by Newmarket." $\ddagger$ These dykes are the largest

* "Saga-Book of the Viking Club," Jan., 1905.

†"Earthwork in England," p. 506.

¡ Copinger's "Manors of Suffolk." 
in Britain, and Mr. Allcroft points out that "it is certainly curious that the people who reared the Devil's Dyke and Fleam Dyke should apparently have constructed no analogous defences in the shape of camps. Probably the difference of race between the inhabitants of East Anglia and those of the rest of the island goes back to very early times." He asserts that the builders must have been a powerful and numerous people, and suggests that the dykes were erected by some of the Belgæ (Iron Age immigrants with the Brythons), and were strictly military works for the protection of the land in their rear, older than the important road which they cross, and apparently the work of invaders coming from the east. It is at the Cambridgeshire ditches that the great battle between Ostorius and the Iceni, about 50 A.D., is supposed to have taken place, and Mr. W. Johnson, F.G.S., suggests that the Devil's Ditch was made at this time to keep back the Romans. $\dagger$ Professor Skeat, arguing from the name Fleming-dytch Hundred, ascribes the Fleam Dyke to the Fleming invasion in B.C. 60 .

In the time of Henry III., a street in Newmarket was known as "Ykenildeweie," as proved by a conveyance of that date, formerly in the possession of Mr. Arthur Tavlor, F.S.A. The course of the Way between Newmarket and Kentford is uncertain, but it seems probable that it originated the present highway to Bury St. Edmund's, which was not a made road till the beginning of the 18th Century. The Way, judging by the boundary between Suffolk and Cambridgeshire, appears to have been on the right of the present highway until just past the second milestone from Newmarket, and then on the left of the road as far as Kentford, where it crossed the Kennet by a ford still visible, and diverged north-eastward from the highway half a mile west from the present bye-road to Cavenham, in which it soon merges.

In describing the road from Bury to Mildenhall, Kirby, in the "Suffolk Traveller," mentions " at $9 \mathrm{~m}$. the right to Icklingham, the left to Kentford." This apparently refers to the Icknield Way in Cavenham. Between Cavenham and Lackford Bridge the Way crosses Cavenham Heath, on which there are two earthworks known as "Black (Ditches," about $1 \frac{1}{2}$ mile apart, and a line connecting them would intersect the Way. The fosse is on the west side in both cases. The more westerly section is 3 mile long, the northern end starting in the marshy ground by the river Lark, and the southern end terminating abruptly. The portion nearer Risby is much better preserved and occupies a dominating position at the top of a slope. On the south side of the river Lark, adjoining Lackford Bridge, the ancient approach to the ford may still be seen.

* “ Earthwork in England," p. 183.

†"Folk-Memory," p. 73 ; also Conybeare's "Roman Britain," pp. 


\section{Lacikford Bridge to Marmansgrave.}

Though there is little doubt that the Icknield Way crossed the river Lark at what is now Lackford Bridge, and thence followed the houndary of the Blackbourne and Lackford Hundreds to Thetford, some confusion has been caused by two ancient ways, which crossed the river further westward, one at Temple Bridge, west of Icklingham St. James, and the other a little west of the Pilgrim's Path which runs north-east from Icklingham All Saints' Church. The former was for a long period part of the London Road between Thetford and Newmarket. It was close by Temple Bridge that during the Peasants' Rising in 1381, Bishop Henry le Spencer, travelling from Cambridge and Newmarket, met John Litester, the Norfolk leader, with two hostages and three followers on his way to the Court of Richard II. Capgrave says that the Bishop "came to Icklingham at a spot where a mill somewhat narrowed the roadway between Cambridge and Thetford," and Blomefield, in explanation, says* that "at that time the great road which now (1739) goes throngh Barton Mills, went through that town at a place still called Temple Bridge, by which there was then a mill, and houses for reception for all travellers; the passage from the river to the fields was a narrow lane." In Sir T. Smith's "De Republica. Anglorum" (1641) the distance from London to Norwich is given as 95 miles, Newmarket to Icklingham sands being 10 , on to Thetford 6, and thence to Attleborough 10 . Ogilby's road map of England (1644) shows the main road going through Icklingham. It seems probable that the present northwesterly course of this road from Temple Bridge was not the original one, but that it went north-eastward and joined the Icknield Way at Shelterhouse Corner, for Kirby's "Suffolk Traveller" (1764), describing the road from Bury to Brandon at $8 \mathrm{~m}$. $5 \mathrm{f}$. from Bury, gives the right turn as to Thetford (this would be the Icknield Wav) and the left to Icklingham, while at $10 \mathrm{~m} .2 \mathrm{f}$. the present main road from Newmarket to Thetford is crossed. Unless the Cld London Way joined the Icknield Way sonth of this point it is unaccounted for. Ten tracks formerly met at Shelterhouse Corner, and recent maps of Suffolk mark one of these as coming from Temple Bridge. That the Icknield Way formed the old London road from Thetford seems proved by several references. In a description $\uparrow$ of the Liberties of the town in the reign of Edward I., one boundary is " ad pontem de Lacford versus Novum mercatum," in $1585 \%$ " the way leading from Thetford to Jackford, called Old London Way," is mentioned, and there is a further reference to "Lackefordeweye, alias Salter's Way." It seems impossible, bearing in mind the contiguity of the Icknield Way and the present main road between Elveden and Thetford, for any road from Temple Bridge to Thetford to have reached the latter town

* "History of Norfolk," Vol. III., p. 109.

$\dagger$ Martin's " History of Thetford," Appendix, p. 123.

† Ibid, p. 193. 

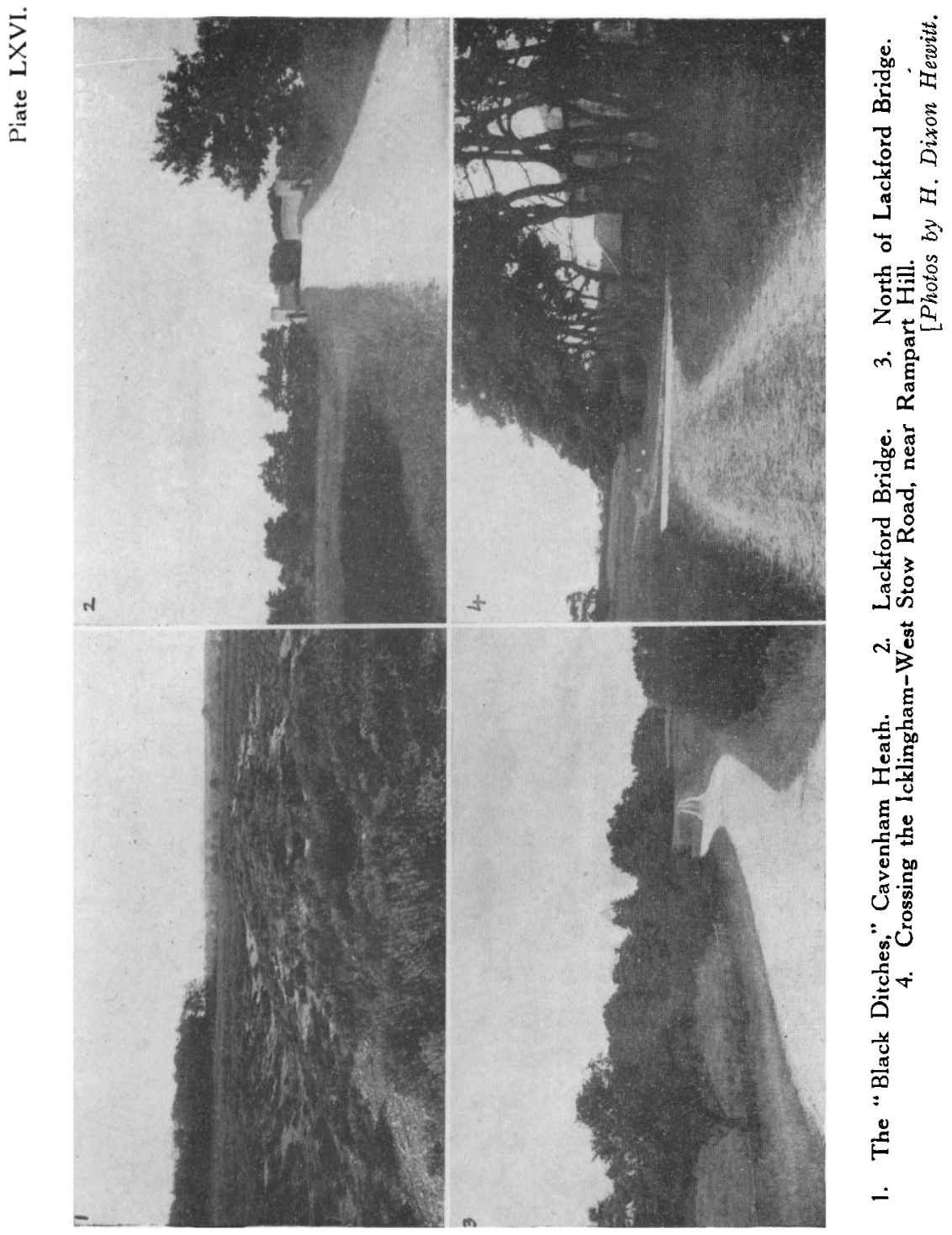


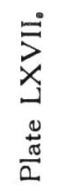
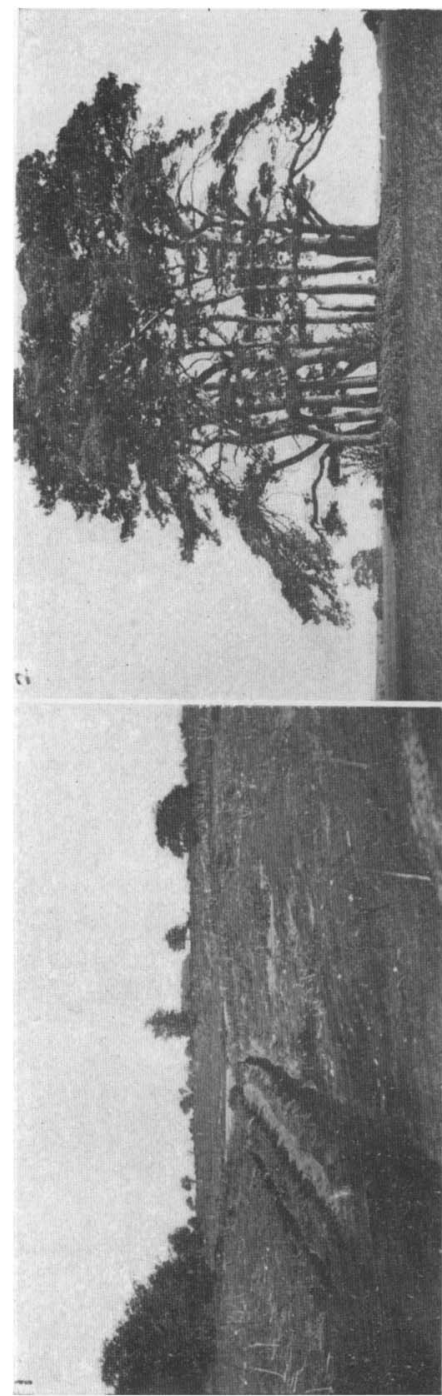
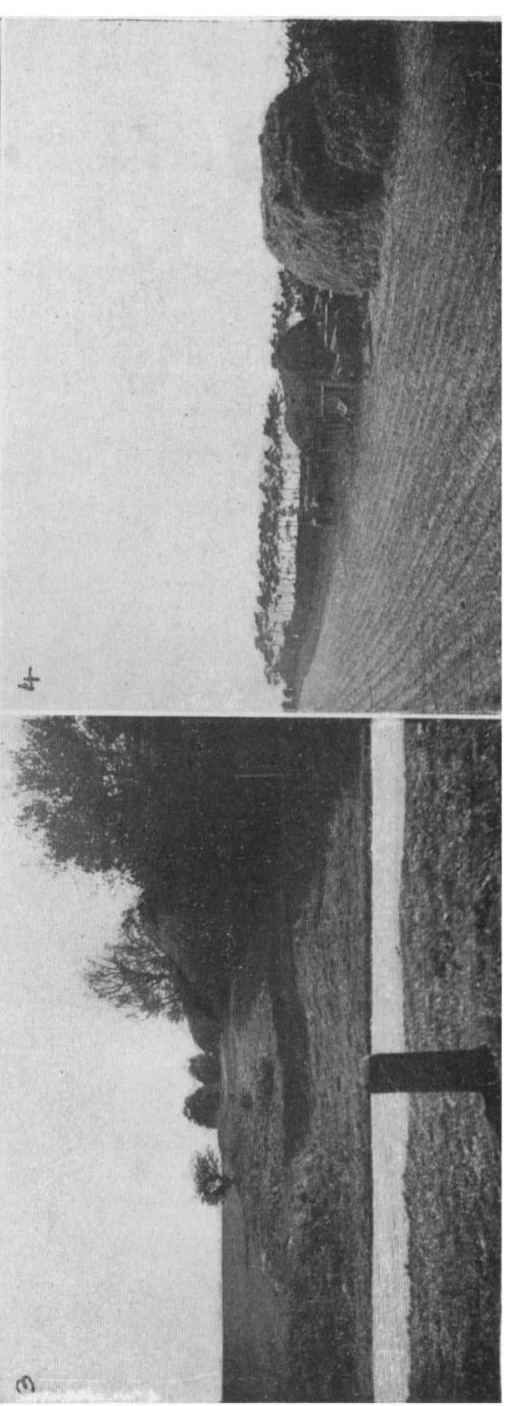

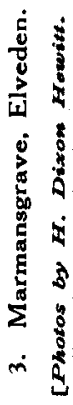

逭

:

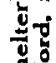

ง

管

\&

3.

象

i

ปูป

W

:

苞 
other than by the Icknield Way. North of the Lark, at Temple Bridge, the Old London Road passed Camp Close, where it forms a hollow way on the heath, thence by London Bottom and a barrow called "Deadman's Grave." Eastward there are six barrows in Icklingham between this road and the Icknield Way. South of the Lark it may have rejoined the Icknield Way at Cavenham, or gone by Tuddenham and Herringswell to Newmarket.

Though quite at the extremity of the Hundred, the ford of the Lark on the Icknield Way gave its name to the Lackford Hundred, as did the Blackwater ford of the Little Ouse on Peddar's Way to the adjoining Hundred of Blackbourne, and the big earthen bank which borders the Icknield Way between Lackford Bridge and Thetford is still the boundary of the two Hundreds. After passing Leech Moor the Way climbs the valley-slope of the Lark by a splendid stretch of turf known as "The Gallop," and there forms the boundary between Icklingham and West Stow. At right angles to the Way there are several huge earthen banks-some 30 feet wide-said to be " trapping banks for rabbits," but probably, in their original state, banks and ditches thrown up in connection with the Way, the ditches having been filled in by blown sand. Some of the banks which have been trenched appear to have been made solely of blown sand, as no stone of any kind was found in them. From the crown of the ridge above the Lark, the view from north to south covers a distance of 18 miles. Between Lackford bridge and the road from Elveden to Wordwell the Way is well defined, banked on each side, and used as a public trackway. For the most part it consists of closely-cropped turf, but here and there bracken and furze and heather endeavour to encroach on it, but with little success. As on Peddar's Way, while the general direction of the road is straight, its course is serpentine. The crossing of the Wordwell road is variously known as Shelterhouse (the ancient form) or Sheltereye Corner, or more generally as Old Elveden Gap, probably because the Way here cut through the parochial boundary bank. The Way is here about 40 feet wide, and 173 feet above O.D., dropping to 80 at Marmansgrave, and again reaching 100 feet at the top of the slope to the Little Ouse. Between Shelterhouse Corner and Marmansgrave the Way, which is in the parish of Elveden, is impassable to any but a pedestrian. Hillocks of blown sand covered with sand-sedge have in places obliterated the track, rabbits have burrowed all over the road, vegetation has been allowed to grow unchecked, and straggling branches of the tall hawthorns check the progress of the incautious traveller.

\section{MARMANSGRAVE TO RoudhaM.}

The crossing of the Icknield Way by the road from Barnham to Elveden is known as Marmansgrave. Local tradition asserts that "Mar" was a gamekeeper who, when found off his beat by poachers, was shot in accordance with their threats. More probably, however, a suicide was interred at the crossways. When 
this took place there is no means of knowing, but in a case before the Court of Augmentation in the 16th Century, references to "Deadman's Grave" and "Deadman's Lands" seem to refer to this locality. I-ess than a century ago a road known as the "Mildenhall Road" ran straight from Marmansgrave to Elveden tollgate. From this point to Thetford the Way is traceable, but not open. It first follows the east side of a plantation in a north-westerly direction, and then curves round to the north-east. From Marmansgrave to the boundary of the borough of Thetford is one mile. In the time of Edward I. a bank called Londmere formed the boundary between Thetford fields and the fields of Barnham, Elveden, and Santon Downham, and between the Liberty of Thetford and the Liberty of St. Edmund. This bank still forms the southern boundary of the borongh of Thetford, possibly because a thousand years ago King Edward the Confessor ended a charter to Bury Abbey as follows:-." If anyone shall be so maddened by the incitements of the devil that he determine to alter the boundaries of St. Edmund's Liberty, or to nullify it or spoil it in any way, let him be anathematised or drowned in the fire of hell, unless he come to his senses in this life."* In 29 Elizabeth, it was stated that there was a great boundary called Port Mere, which began at Skatchowe in Elveden and extended " to the late cross which divides the lands of Thetford, Elveden, and Barnham." $\dagger$ The Icknield Way formed the boundary between the parishes of Elveden and Barnham, so that the cross stood where that trackway entered the bounds of Thetford. In 1585, the wooden cross which stood at the junction of the three parishes was known as Barrow Cross. The course of the Way adjoins Thetford Cemetery on the east, and the top of the slope from the river south of this spot was in the 18th Century known as London Hill. Continuing its northeasterly sweep, the Way crossed the present Bury Road north of the Gasworks and the old Euston Road at "Chunk Hervey's Grave," a short distance from the ancient fords. Tradition asserts that "Chunk Hervey" was a pirate, who was betrayed by a former comrade, hanged, and buried here. A century ago a tree here was said to have grown from the stake with which his body was pierced, this pointing rather to the burial of a suicide at the four crossways. "Weaver's Close," which adjoins the grave, was marked by Thomas Martin in a MS. plan of Thetford in 1740 as "The Camp." The Way first crossed the Little Ouse at the Nun's Bridge, anciently " Incelland Bridge," where scolds were ducked in the cucking-stool, which was described in 1392 as " by Nun's Bridge in Bailey End," over a narrow tongue of the Guiltcross Hundred in Norfolk-- the Little Ouse being the county boundaryand thence over the Thet at a spot marked as "Old Ford" in Burrell's Map of Thetford, 1807. Its pre-eminence in Saxon times is indicated by the name of the town, which is simply Thaet-ford,

* Mackinlay's "St. Edmund, King and Martyr," p. 374.

+Martin's " History of Thetford," p. 194. 
thaet being the neuter form of "the." Then the Way crossed what was the Market Place until the removal of the market in 1786, the ancient inns denoting its former importance. Here stood the market cross, and in 1408 the Austin Friars had permission to build a hermitage at the west end of the church adjoining the street, where they received alms. The Friary was in 1509 described as " in ye market stede in Thetford." Thence the Way passed through the Castle Hill earthworks, the largest in East Anglia, and by Gallow's Pit, where Martin in his MS. plan of 1740 has drawn a gibbet. This would be in accordance with early usage, as criminals were usually gibbeted by the most frequented public roads. The Way continued by Green Lane; which in the Thetford enclosure award of 1806 is described as "Kilverstone Road." The superior Leet of Kilverstone was held by the Lord of the Hundred of Shropham at the stone cross, and there also the Leet of the Hundred was sometimes held, a further proof of the early importance of the place. Until a few years ago the base of an old cross stood in the yard of Kilverstone Hall. The Way entered the parish of Kilverstone close by the present railway crossing on the branch line from Thetford to Bury St. Edmund's and for a mile onwards is even now a typical prehistoric trackway, sandy, with deeply rutted turf, first bordered by low fir hedges and ancient elders, and then by a fine avenue of trees. The continuation of Green Lane appears to have been closed when "Maiden's Walk" was made, but even now ploughmen can distinguish its further course by the greater hardness of the soil. In one of the fields between Green Lane and Roudham Heath, five hawthorns would seem to indicate the ancient track, which is continued by three in the next. On Brettenham and Bridgham heaths there are still traces of a traditional "wagon road," probably part of the Icknield Way between the ford at Thetford and the ford at Iarlingford, though it may be assumed that this portion of its course was little used after the beginning of the 17th Century. The present Norwich highway is marked in Ogilby's Road Map of 1675. In Robert Morden's map of Norfolk in 1695, and in a map of 1713, the present turnpike between Thetford and Larlingford is, however, not shown. The Norwich highway crosses the rivers Thet and little Ouse at the Nun's bridges, and runs northeastward by way of Green Lane. In W. H. Toms' map of Norfolk (1742) "Kilverston" is shown on the main road from Thetford to Norwich. In 1749 the present road was shown on a map of the county in addition to the old one. This was the case in 1777, but in 1808 the old road is omitted, and the same in Laurie and Whittle's map of Norfolk and Suffolk in 1811. However, in a map of Norfolk by Mr. Thomas Dix (1816), in C. Smith's map (1801 and 1804), and John Cary's map (1807), a continuation of the Green Lane is shown running parallel with the present highway until it unites with Peddar's Way on Bridgham Heath. This road is also shown on one of Gall and Inglis' most recent maps of Norfolk, though Green Lane is omitted. It seems most probable, as shown 
by Emmanuel Bowen's map of Norfolk in 1749, and James Corbridge's map, that the Icknield Way originally formed the boundary between the Hundreds of Shropham and Grimshoe.

Evidence as to its further course in Norfolk is lacking. Mr. J. C. Tingey, F.S.A., suggests that the route was from Old Elveden Gap, over the Little Ouse at the south-east corner of Barnham Cross Common, over Snarehill by Shadwell Park to the Harlings, by Uphall and Kenninghall to Banham, Mulbarton, the division of the parishes of Swainsthorpe and Dunston, Stoke Holy Cross, Poringland, and Haddiscoe. In 1363 there was a Salter's Waye in Banham, which extended to the fields of Wilby, and a Tycknald Street, and then twelve miles distant, between Swainsthorpe and Dunstan, is Hickling Lane, referred to in a 17th Century conveyance as Icklinge Way, and in 1482, in Dunston, as "Hiclynge Weye." Mr. Tingey admits that there is no trace of the Breckland portion of this route. The Rev. Dr. Astley suggests a course from Thetford to Kenninghall, Banham, Long Stratton, and Tasburgh, but of this also-at least so far as the Breckland portion is concerned-it may be added that there is no trace either now or in mediæval documents. Neither of these routes could reasonably be connected with the obvious continuation of the Way from Thetford by the Green Lane to Kilverstone, and thence to Roudham.

It is doubtful whether the present road from Larlingford to Norwich is of great antiquity as a main road. H.H. Prince F. Duleep Singh informs me that there are in the Hargham plantations two stone crosses, both north of the present high road, one not more than 20 yards distant, but the other on a track considerably further away, which may mark the line of the old road. When in 1599 Will Kemp danced from London to Norwich, he went from Thetford by way of Rockland and Hingham, and Ogilby's "Britannia" (1675), which first marks the present road, shows that even then "Attleburgh Meer," a big expanse of water, reached quite across the modern highway.

\section{Cultural Remains.}

Neolithic implements are found along the whole course of the Way in Cambridgeshire, Suffolk, and Norfolk, but particularly in the Suffolk portion, in the parishes of Cavenham, Lackford, Icklingham, and West Stow. Dr. W. Allen Sturge has described* Icklingham as " the very centre of the most prolific area in this very prolific part of the country from the point of view of the Stone Age." The flint implements in these Suffolk parishes are numbered by the hundred thousand. It is also of considerable interest to note that more than a dozen finely-chipped dagger-handles of Danish type in Dr. Sturge's collection were found along the Suffolk course of the Icknield Way, nearly all in North Stow. Dr. Sturge says :-." They are an extraordinarily interesting series, and represent several types of the dagger. They are, I think, all Neolithic, 
and not Bronze Age-some of them, I should judge, not of the latest Neolithic. I expect that when the handles broke they were thrown away by their owners, and the blades reworked for further use, and taken away to Denmark or elsewhere. My handles for the most part have been of very fine pieces. The evidence from these handles would go to show that the Icknield Way was in being before the Bronze Age. I have also a hollow-based arrowhead of Danish type, found near here." Both chipped and polished implements have been found in Newmarket, Cavenham, Lackford, Icklingham, West Stow, Elveden, Thetford, and Kilverstone, and some of the fields bordering the Way abound in Neolithic flakes and implements.

Bronze implements have been found at Heydon, Newmarket, Cavenham, Icklingham, West Stow, and Thetford. There are numerous barrows on the Downs near Royston; on Newmarket Heath are the Beacon Hill tumuli, in which cinerary urns, described as "British," were found; the Way passes three barrows in Kentford, several at Cavenham, two (one known as "Jennet's Hill ") in West Stow, while there are six in Icklingham, between this road and that from Temple Bridge to Shelterhouse Corner. Between this spot and the Duke's Ride, near "Barrow's Corner," is a barrow planted with fir-trees. It is slightly oval in shape, with a circumference of 60 paces, and a height of about 3 feet. Close by the Way in Thetford Cemetery was a barrow in which were found, about 1868, cremated human remains with charcoal and flint flakes.*

At the southern end of Wool Street are the War Ditches, Cherry Hinton, which, with a diameter of 450 feet, constitute a typical plateau-fort of pre-Roman date, the slope being almost perpendicular. Recent excavation $\dagger$ has disclosed pre-Roman interments, and in the fosse cooking-pots were found set upon flat griddles of thin stone resting on four struts of burnt clay. In the field adjoining Thetford Gasworks, crossed by the Way, have been found numerous pit-dwellings, sometimes in pairs or in groups of two or three communicating with each other. These contained charcoal, pottery with great variety of shapes and ornamentation, numerous bone needles, and "stone and bone amulets." This was in 1870, but of recent years bushels of horn-cores of the long-faced ox have been disinterred, and I have a wild boar's tusk dug up there in 1904. In digging the foundations of the Corporation dwellings in 1912, many Romano-British potsherds of grey paste were found by $\mathrm{Mr}$. H. Dixon Hewitt, but only two pieces were ornamented. One had rectangular lattice-work, and the other diamond-shaped. While laying a sewer on Bury Road, where it was crossed by the Icknield Way, two bases of large red-deer antlers, sawn off a few inches above the burr, were found, and correspond with others of Late Celtic date. Between the river Thet and the Way at the Thetford end of Green Lane was a similar British settle-

* Hunt's "Capital of the Ancient Kingdom of East Anglia," p. 184. +" Antiquary," Jan., 1909. 
ment, in which pottery, animal remains, and a "beautiful stone amulet " were found in 1870 .

Roman antiquities have been found in the Five Barrow Field, near Royston; and Roman coins at the Bran Ditch, and (with Roman urns) at the Devil's Dyke. Not far from the Way is the Roman station at Great Chesterford, where numerous finds of great interest have been made, while a Roman villa was also found at Ickleton. West of the Way, north of Lackford Bridge, is Rampart Field, Icklingham, which was enclosed by a ditch and rampart. Here, and in the immediate vicinity, have been found the remains of Roman villas, of a Roman cemetery, and coins of the 4th Century, A.D. Roman coins were not uncommonly found in Elveden in the 18th Century, as recorded by the Rector, the Rev. G. Burton, in a letter to the Rev. W. Stukeley, D.D. A number of Roman coins have also been found in Thetford.

There was an extensive Anglo-Saxon burial-ground near the Beacon Hill tumuli on Newmarket Heath; and an even more extensive one was discovered near the Way at West Stow in 1851, about 100 skeletons, with urns and iron and bronze implements, being disinterred. During the Anglo-Saxon period, Thetford was the chief town in East Anglia, and adjoining a mile of the Icknield Way were eight of the churches, and subsequently the cucking-stool, market cross, shirehall, and gibbet, and the huge Castle Hill earthworks, which may possibly have originated in prehistoric times.

\section{Conclusions as to Age.}

From the evidence of the antiquities on its course, and from numerous analogies with prehistoric trackways, there seems little doubt that the Icknield Way was in use in the latter part of the Neolithic Age, and continued in use throughout the Bronze and Early Iron Ages. It is therefore probable that the Way preceded the great Cambridgeshire ditches, which were erected to defend the country in their rear from forces advancing along the Way from the westward. It was utilised by the Romans, who erected defences at some of the most important strategic points, but that it preceded them seems demonstrated by the fact that nowhere does it lead directly from one Roman settlement to another. Neither did they re-make it, and for the greater part of its course it is still in its primitive unmade condition, a winding track over chalk ridge and sandy heath. There is ample evidence that the East Anglian portion was an important highway in Saxon times, and it so continued throughout the Middle Ages, remaining one of the chief highways into Norfolk from the west and south-west until the end of the 17th Century, when it was superseded by turnpike roads. It still remains in use, however, for slow-moving traffic, particularly cattle and sheep, and was so used from Thetford south-westwards until about 1830. An 1804 map of Suffolk shows its course quite from Thetford, though the portion near the borough has since been enclosed. 